\title{
The Space of Zurab Tsereteli's Creative Personality in World Modern Art
}

\author{
Lyubov V. Shirshova ${ }^{1, *}$ \\ ${ }^{1}$ Russian State Specialized Academy of Arts, Russian Academy of Arts, Moscow, Russia \\ *Corresponding author. Email: lshirshova@rah.ru
}

\begin{abstract}
The present paper is dedicated to the creative work of a master of international renown, Zurab Konstantinovich Tsereteli. Various aspects of his many-sided activities as a sculpture-pioneer are described here. Basing on the works of Tsereteli, the author analyzes a broad picture of developments in the national artistic culture, individual features of the master's craft that have come through both his monumental and indoor works.
\end{abstract}

Keywords: creative many-sidedness, monuments, monumental compositions, academic schooling, national traditions, openness to the outside world, synthesis, out of door museum of sculpture

\section{INTRODUCTION}

The name of Zurab Konstantinovich Tsereteli, President of the Russian Academy of arts, has long been included in the annals of world art history. As an artist of the Renaissance type, versatile, widespread creative personality, the master successfully works in many types and genres of plastic arts. The value of $\mathrm{Z}$. $\mathrm{K}$. Tsereteli, as a sculptor, cannot be overestimated. Master has created works that have left an indelible mark on the world culture. The creativity of Tsereteli the sculptor, allows him to combine the art of the XX and XXI centuries. Since the 1960s, he has created more than a hundred monuments, sculptural and architectural ensembles, monumental and decorative works, and relief compositions, memorials and plaques. The artist-thinker, a deeply creative person, he combines artistic activity with intellectual and scientific spheres. As a great creative personality, he always strives to say a new word in art. Thanks to his creative position, he acts as an innovative artist in many areas. One of the first, he began to revive religious themes in the Russian domestic art of the twentieth century, and to create monuments to the Holy and great Christian figures, for example, St. Nina (1988, Tbilisi, Georgia), St. Nicholas of Myra (2012, Bari, Italy).

He has continued a tradition of creating the sculptural decoration of Orthodox churches on a modern level (Church of St. George on Poklonnaya Hill. Moscow.) In 1995, during opening of this monumental complex, Y. M. Luzhkov, the then mayor of Moscow, said that "the Church of St. George on Poklonnaya Hill is created in the best traditions of Old Russian sculpture as it is decorated with unique reliefs striking visitors by their pure harmony and nobility of features. [1]

At the end of the twentieth century, Tsereteli, as the chief artist, President of the Russian Academy of arts, and a master of monumental art, started leading the process, in many ways unique, of recreating the sculptural and picturesque decoration of the Cathedral of Christ the Savior in Moscow. Nowadays, Z. K. Tsereteli heads the creation of monumental mosaic decoration of St. Sava Cathedral in Belgrade, synthesizing fine arts and architecture on a new level.

Z. K. Tsereteli has revived and improved a number of traditional crafts, for example, the lost technique of the Georgian art cloisonne (X - XII centuries), and he was the first to use this technique to create monumental compositions. It should be noted that he is an artist who masters a number of unique techniques, for example, the creation of work of authorship in bulk enamel.

One of the first in the Soviet Union, Tsereteli began to work in design. Having shown outstanding managerial talent, he took charge of the Union of Designers of Georgia. A lot of original in the modern art world is connected with the name of $\mathrm{Z}$. K. Tsereteli.

\section{THE FEATURES OF ART STRUCTURE AND FORM IN THE MONUMENTAL ART OF ZURAB TSERETELI}

The urge to say a new word in art forced him to take training at the Tbilisi Academy of arts (1952-1958) from such great artists, innovators, extraordinary personalities as A. I. Charlemagne, V. K. Shebuev, V. I. Shukhaev. His contacts with the great Pablo Picasso, Salvador Dali, Sergei Konenkov, Marc Chagall, and 
Oscar Niemeyer contributed to the acquisition of creative freedom, courage, and the openness of the master's art. On passing the academic schooling, Zurab Tsereteli worked for several years participating in the Academy of Sciences of the Georgian SSR in ethnographic expeditions, studied material and spiritual culture, traditions, history, the art of ancient and medieval Georgia. The national cultural tradition had been the starting point for the artistic development of $\mathrm{Z}$. K. Tsereteli. This contributed to the synthesis of national, classical and realistic artistic traditions in his work.

At the same time, the beginning of creative activity of Tsereteli coincided with the formation of new creative directions in the art of the "sixties", which strongly manifested in the visual arts in Russia. The revival of deeply hidden national traditions and the gradual abandonment of the ideological schematic socialist realism together with concurrent global social and political changes in the life of Russia led to the renewal of many types and genres in the Russian domestic artistic practice of the 1960s-1970s.

The art of Z. K. Tsereteli from the very beginning of creative period was the art of individuality, asserting his artistic ego. After graduating from the Pictorial Department of the Academy, he began to work as a muralist starting from early 1960s. Since that time, painting and sculpture coexisted in his work in parallel. In 1967, he completed a large his own creative work related to the monumental and artistic design of the resort complex in Pitsunda. In his monumental and indoor sculptural compositions, he sought to produce a holistic generalized expressive image, always selecting the essence that allows conveying the universal meaning of the work.

Analyzing the proficiency of Z. K. Tsereteli of the 1960s, academician, doctor of art D. O. Shvidkovskiy in one of his speeches noted that "monumental art has become a leading feature in his creative method.

Developing the issues of synthesis of arts at a new level and a comprehensive approach to solving the spatial environment, Tsereteli created the artistic decoration for many socially important buildings and architectural ensembles. He designed large-scale projects in Adler, Tbilisi, Ulyanovsk, and Moscow and in many cities around the world. Working as the chief artist of the USSR Foreign Ministry (1970-1980), and afterwards as the chief artistic director of the "Olympics - 80" in Moscow, he showed his worth as an artist of universal abilities, with a broad knowledge of the artistic and humanitarian domains, in many technological processes of various arts and urban planning. While getting acquainted with the monumental works of 1960-1970 is by Z. K. Tsereteli, a great artist David Alfaro Siqueiros wrote in a telegram to the master in 1973: "On my own behalf and on behalf of the mural artists of Mexico, I congratulate Zurab Tsereteli for the artistic merits of his work at the Palace of Culture of Trade Unions in Tbilisi and at the resort complex of Adler. Zurab Tsereteli grasps the intricate technique of wall painting with the great plastic ability and creative imagination. I claim that he has entered the vast expanses of the art of the future. Art that combines sculpture with painting. Zurab Tsereteli's work has gone beyond the national framework and is gaining international importance. " [2]

The calibre of his personality developed thanks to the acquaintance with great people of art, great artists of the era, and his closeness to the events of historical significance and the ability of Tsereteli to absorb and rethink a lot. The work of the master in the 1960-1970s shows that he was quickly becoming the leader of his generation. Artistic practice in different countries of the world contributed to the active evolution of his art, wide professional and public recognition.

\section{THE DEVELOPMENT TRENDS OF ZURAB TSERETELI'S ART IN THE CONTEXT OF WORLD ART CULTURE}

The growth of professional skill, extent, and independence in confirmation of his intention developed Tsereteli's talent as of a Renaissance artist, which clearly expressed itself in the statement of his individual manner and ability to create monumental bold original works dedicated to socially significant topics and historical events in the 1980-2000-s. A master-humanist with a keen sense of modernity, he has always been extremely sensitive to the processes taking place in the world. Such large-scale sculptural ensembles as "Destroy the wall of distrust" (1988, London), "Friendship forever" (1983, Moscow), "Good conquers Evil" (1990, New York, USA), "the Birth of a new man" (1995, Seville, Spain), "300th anniversary of the Russian Navy: Peter I" (1997, Moscow) "In memory of victims of terrorism worldwide" (2005, New York, USA) and others brought him wide international recognition. Each of these works is a bunch of diverse artistic ideas, with elaborate figurative structure. The works do reflect the individual master character and go beyond certain limits of style forms.

An important material for the practical solution of a wide range of professional problems was the creation of monumental works in the Moscow city environment. Here, in 1995, under his leadership and active participation, the creation of a large-scale memorial complex "Poklonnaya Hill" was completed, and two years later he implemented a largely innovative artistic and design solution of Manezhnaya Square. Tsereteli has demonstrated new means of image synthesis in these big and generalized architectural and sculptural 
ensembles, as well as solution of large scale tasks of urban development.

A researcher Y.Volchok writes in his paper "A sculptural composition, a memorial, a commemorative structure - all these not only and not just play a representation function, they are more important for the urban development" [3]. In 2014, in the historical part of Paris, near the Notre-Dame Cathedral, Z. K Tsereteli created a monument to Pope John Paul II. In connection with this event academician D.O. Shvidlovsliy wrote "It is a very hard task for an artist to add something new to this one of the perfect and beautiful ensembles of the world. Zurab Tsereteli has managed to do this. His sense of master has helped him to grasp and understand the very nature of this two centuries old space" [4].

When creating portrayal monuments of prominent people, Tsereteli is committed to a many-sided explanation of the historical meaning of his model in a sculptural manner. He introduces architectural forms into compositions of his monuments (a monument to Rudolf Nureyv in Kazan), as well as the items describing actions of the model, for instance, the monuments to I. I. Shuvalov (2000, Moscow) or Honoré de Balzac (2017, France).

Numerous monumental works of the master are inextricably linked with the urban and natural environment. In 2016, Z. K. Tsereteli completed installation of a 126 meters high sculpture of "Birth of the New World". The grandiose monument is set on the Northern coast of the island of Puerto Rico in Arecibo. The place was not chosen by chance. It was exactly the place where the legendary Spanish navigator Christopher Columbus landed on the shore in 1492. The figure of Columbus at the handwheel of legendary "Santa Maria" is in the center of composition dedicated to the 500th anniversary of discovery of America. It is a powerful creation, a real embodiment of the unique artistic idea together with innovative trends of shaping, technology and spatial solutions.

Attention to history and to prominent personalities has always characterized the work of Z. K. Tsereteli. In 2017, the sculptor, keenly aware of the current time, opens his "Avenue of Rulers" of Russia, starting with Rurik. Expressive portrait busts of old Russian princes, tsars, Russian emperors and Soviet leaders are installed in the Park of the former Turgenev-Botkin Estate in the center of Moscow, in the Petroverigsky Lane. Now the manor house is occupied by the Museum of military uniforms and clothing and by the Russian militaryhistorical society. In 2018, work on the sculptural cycle continued, and on the memory day of the first Russian President B. N. Yeltsin, his monument-bust was inaugurated at the "Avenue of Rulers" on April 23. Of the author, who was closely familiar with the model, this work required deep insight. The sculptor managed to convey not only the portrait likeness, but was also able to reflect character of this statesman. Y. R.Saveliev writes in his book "The images of monarch actually do personalize the most important periods of national history, benchmarks of our culture and art development, progressive reforms, and critical times in the country history" [5].

In this portrait gallery the sculptor proved himself to be a real historiographer and psychologist. He studied iconographic artefacts, dresses, and awards of the past to make a sculpture of a historic personality. "Avenue of Rulers" created by Tsereteli has become now an important reminder of our vision of the world and cultural traditions. Timeless images of Russia's history continue their life now in bronze.

During his long creative life, Tsereteli produced a portrait gallery of outstanding musicians, poets, artists, actors, of the people whose work considerably formed and continues to form the spiritual basis of modern culture. By the nature of his work, Zurab Konstantinovich, a world-class artist, teacher, statesman and public figure, collector, philanthropist, a UNESCO Goodwill Ambassador, is well acquainted with many great contemporaries. Academician A.A. Zolotov writes in his article: "Poetry of perception of reality, inherent to Tsereteli and his works, can make a symbol out of the object of his portrait as well as remove this object from the sphere of admire and put it into the other one, a psychologically convincing sphere which helps you recognize the human essence of the portrait hero... " [6]

In early 2000s, he created a brilliant and largely innovative series of high reliefs of bronze "My contemporaries" (displayed in the Art Gallery on Prechistenka Street) with portrayal images of Vladimir Vysotsky, Andrei Dementiev, Joseph Brodsky, Vasily Shukshin, and many others. Created by Z. K. Tsereteli images testify to the spiritual priorities of the time, they are a unique collection of truthful, vital, documentary evidence of our not easy era.

The sculptor addressed more than once to the embodiment in bronze of images of poets of the Silver Age. The master has a special attitude to the personality of Marina Tsvetaeva, a poet with an incredibly difficult and tragic fate. Her image is in a series of author's reliefs and in the monument erected in France in the city of Saint-Gilles-Croix-de-Vie. On a sunny day of May 14, 2018, in Moscow, the poetess's birthplace, in the territory of gymnasium № 1619 named after M. I. Tsvetaeva, a grand opening of the monument dedicated to her was held. The author genuinely thought out an elegant simplicity of the sculpture. Marina Tsvetaeva is sitting on a bench with a flower in her right hand. The artist talent is seen in a well-balanced and at the same time dynamic composition expressing anxiety of a slender figure of this young woman. Skilled use of artistic properties of bronze and plastics of the work 
increase our understanding of a harmonious and sublime image of the poetess.

The unveiling of a monument to poet Robert Rozhdestvenskiy took place on 23 of June in his "small motherland" in Kosikha village in Altai region. His home people warmly received Z. K. Tsereteli's work showing a deep image of the man of integrity, who is our contemporary.

Zurab Konstantinovich has created archetypes of the history of world art. In July, he presented sculptures of geniuses of the Italian Renaissance - Michelangelo Buonarroti and Leonardo da Vinci. The choice of the master's models is logical. A few years earlier, he created sculptural portraits of masters of the twentieth century, the following were among them: the founder of abstract art Vasily Kandinsky and one of its main representatives Kazimir Malevich. These sculptural compositions are a kind of plastic dialogue of different approaches to art, a dialogue with time. Leonardo and Michelangelo had achieved a lot on the way of artistic development of reality. For them, Nature was a beautiful deity. Kandinsky and Malevich were of a different artistic generation. In their work, they had moved away from realism, drastically changes structure of artistic image and artistic language in accordance with the development of a new level of art knowledge. The four great masters, men of difficult fates, all dedicated to new ideas of their time, they four emerged as forerunners of the coming global changes in the art.

Thereteli is also well known as a patron of arts. On September, the 8th, he donated to Russian Drama Theatre in Tbilisi, named after A.S. Griboedov, a sculpture of this prominent playwright and diplomat. The sculpture will be mounted in the central lobby of the theatre.

On November the 7th, 2018, Thereteli opened in Kazan the first in Russia monument to the great ballet performer Rudolf Nureyev. He formed a "flying dancer" as if flying on a pedestal made as a column cracked in two places. The sculptor always tried to open the maximum of possibilities his model holds. This particular image concentrates the power and beauty of the dancer personality. Though distorting the form, using conventionality of image and objects interpretation, the sculptor understands perfectly well the importance of the symbol showing significance of artistic image.

\section{THE ETERNAL AND TRANSITORY IN THE ART OF ZURAB TSERETELI}

In his art, modernity and tradition go hand in hand. In the modern world of globalization and destruction of borders between national cultures, Tsereteli addresses to the in indoor sculpture, creation of a large series of images of the citizens of old Tbilisi called "Citizens". I would like to note that this series was originally created in graphics, then in the technique of oil painting, enamel, bas-reliefs of bronze and chamotte and, presently, in the indoor and monumental sculpture. Zurab Konstantinovich is the only artist of our time, who develops his favorite pieces in various techniques and materials. Extensive in-depth knowledge and indomitable creative imagination open up great opportunities for realization of his creative potential. The characters in this series are often depicted in the ordinary surrounding environment. Revealing the main visual idea of sculpture, he shows an incredible diversity of compositional solutions. Later on, Tsereteli repeated the art themes - most important for his work and for the history of art - in various plastic genres, for example, in relief and round indoor sculpture and other techniques, such as he used in a series of "Circus".

In the inner architectural space of the atrium of "The Art Gallery" in Moscow, Tsereteli places monumental bronze reliefs on Biblical and Evangelical themes. Plastic images are complex space-occupying compositions demonstrate the spiritual potential of the master. Importantly that in religious compositions the canonical solution of subjects and traditional iconography are combined with living characteristics of real life.

\section{CONCLUSION}

Tsereteli is one of those rare masters of our time, who, professionally owning many artistic techniques and technologies, continues powerfully and ably to express his creative abilities in a variety of types, forms and genres of art.

Last autumn in the Moscow suburb of Peredelkino Z. K. Tsereteli opened a retrospective out of door exhibition of sculpture in the territory of his housemuseum. This is an invaluable collection of works, testifying to the versatility of the author, his endless love for art and beauty. The master creative individuality is manifested in clear and artistically expressive images created by him. The nature of the artist's spiritual quest is evidenced by the variety of genres and themes he addresses in his work. Synthesis, as a system of author's thinking, penetrates into plastic, constructive, and ideological field of creativity. The artist presents to the audience his unique version of reality, the Universe created by him.

Zurab Konstantinovich professes art as "the highest truth of man". His innovative and deeply original art has long been established in its self-value, and for decades continues to be a striking artistic phenomenon of the modern world art culture. 


\section{References}

[1] Y.Luzhkov. From his speech at the opening of the memorial complex on Poklonnaya Hill. 9 May 1995//This Day of Victory. Album. - Galart, 1996. - 109 p., ill.

[2] Personal archives of Z.K. Tsereteli.

[3] Y. Volchok. A Monument and a City//The art of sculpture in XX-XXI centuries: masters, tendencies, problems. Teamwork monograpg. - M. BukeMArt, 2017. 623 p., ill.

[4] D. Shvidkovskiy. A sculpture by Tsereteli in the heart of Paris// The Tretyakov Gallery. Supplement. - 2018.04. (61)

[5] Y. Saveliev. Power and Monument. Monuments to sovereign rulers of Russia and Europe. 1881-1914. - St. Petersburg: Faces of Russia, 2015. - 296 p., ill.

[6] A. Zolotov. Visual Theatre of Zurab Tsereteli: New realism as a problem of artistic co-proportion of the art and life// The art of sculpture in XX century: problems, tendencies, masters. Essays. Proceedings of the international research conference. Moscow 2006. - M.: Galart, 2010. - 488 p., ill. 